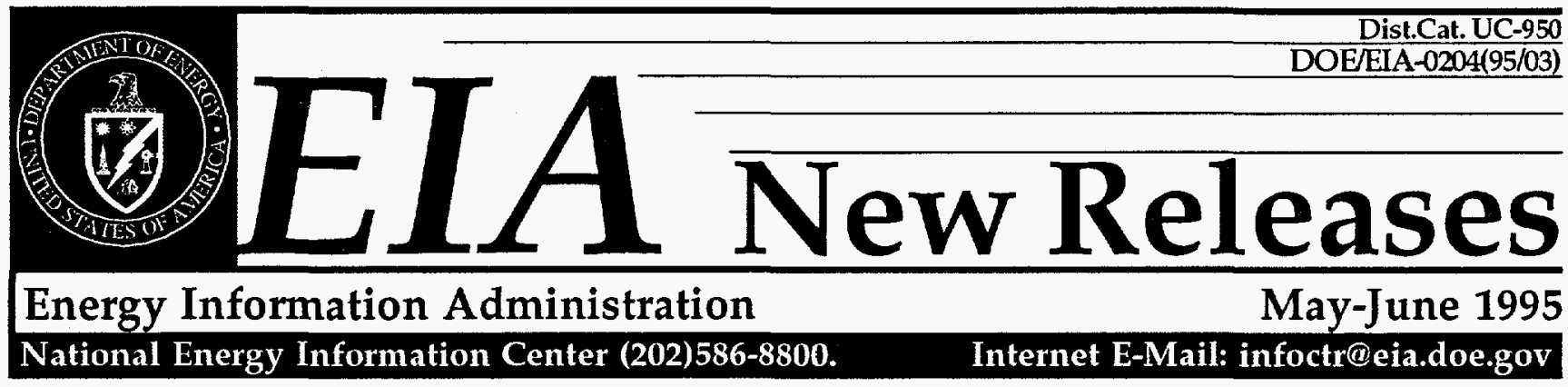

\title{
Recently Released EIA Report Presents International Forecasting Data
}

Oil demand growth in the next $\mathbf{1 5}$ years is projected to become increasingly reliant on supplies from relatively few resource-rich countries, according to a report released by the Energy Information Administration (EIA). The Organization of Petroleum Exporting Countries (OPEC) is expected to supply 52 percent of the world's oil in 2010, compared to its 1994 share of 40 percent. The EIA projection shows Eastern Europe and the former Soviet Union at 13 percent and the rest of the world at 35 percent in 2010.

EIA's International Energy Outlook 1995 (Outlook) projects that, barring any major political event that would affect world oil markets, oil prices will remain stable for the next few years and then rise gradually, remaining below $\$ 25$ per barrel (in 1993 U.S. dollars) through the end of the projection period. World oil demand is expected to grow to 88.7 million barrels per day by 2010 . Electricity is expected to remain the fastest growing form of end-use energy worldwide through

\section{On the Inside}

\section{Building Space and Use of Home}

Appliances Grew in 1980's ..... . 2

Summer Driving Season Gasoline

Prices and Consumption ..... 3

EIA Details Changes in

Household Energy Use ........ 4

Features and Press Releases ...... 5

Visit EIA on the Internet . . . . . . 6

Microfiched Products ........ 7

Electronic Publishing System .... 8

New Reports .............. 9

Machine-Readable Files ....... 12

How To Order EIA Publications ... 13

Energy Data Information Contacts . . 15
2010. In fact, electricity is pected to account for about 42 percent of the increase in total worldwide energy consumption for the 1990 to 2010 time period.

For the first time, the Outlook contains an extensive chapter on electric power, including a regional look at possible implications of the deregulation of this industry. The Outlook projects much of the electricity demand growth to occur in the non-Organization for Economic Cooperation and Development (non-OECD) countries experiencing rapid economic expansion, including China, South Korea, Indonesia, and Taiwan.

Other highlights from the report include:

World carbon emissions (a major source of greenhouse gases) are expected to grow by 1.5 percent annually, reaching more than 8 billion metric tons by 2010 . The share attributed to the non-OECD (continued on page 3)

\section{International EIA Report On Internet}

The database for the Energy Information Administration's (EIA) report International Energy Annual 1993, together with a system for accessing the data, can now be downloaded to most personal computers via the Internet. The database contains information for over 200 countries and is more detailed and often more timely than the information in the printed publication, because the data are updated quarterly.

Internet access can be obtained through EIA's World Wide Web site at http:/www.eia.doe.gov (see article on page 6). To use the database, users need Microsoft Windows 3.1 or higher, a Web browser such as Mosaic or Netscape, and 8 megabytes of free disk space on their hard drive. The personal computer should be an IBM type with a 386, 486, or Pentium processor with at least 8 megabytes of random-access memory. For any questions contact the EIA National Energy Information Center or (202)586-8800.

Released for Printing: August 1, 1995 


\section{Building Space and Use of Home Appliances Grew Rapidly in the 1980's}

U.S. residential and commercial building space in the 1980's grew well above the rate of population growth, according to a study released by the Energy Information Administration (EIA).

The report, Buildings and Energy in the 1980's, shows that residential space increased 19 percent, commercial space 26 percent, and population 10 percent over the 10-year period.

In U.S. homes, appliances became the major source of energy consumption, overtaking space heating. By the end of the decade, American homeowners were paying over $\$ 49$ billion a year to run their appliances.

Buildings and Energy in the 1980's is the first energy consumption report to provide a unified vision of energy use in both residential and commercial buildings and presents energy data that are consistent between the two sectors and across the 1980's. It is also the first report to show consumption of primary electricity in energy source comparisons. Primary electricity consumption represents the energy used to generate the electricity, about three times the energy content of the delivered electricity.

Other major findings of the report include:

* Single-family detached homes greatly exceeded all other residential or commercial building types in number of buildings, total floorspace, energy consumption, and energy expenditures. They accounted for three-fourths of all buildings, more than half of total floorspace, and more than two-fifths of total consumption and expenditures.

*

In residential and commercial buildings, electricity and natural gas were the largest components of energy consumption. In 1990, in residential buildings, primary electricity consumption was nearly twice that of natural gas and four times as much in commercial buildings in 1989.

Energy intensity, the ratio of energy consumed to building floorspace, was greater in commercial buildings than in residential buildings throughout the 1980's. That reflected differences between the two sectors in the uses of energy and the degree of building occupancy. Primary electricity and natural gas intensities were at similar levels in residential buildings, while primary electricity intensities were much greater than natural gas intensities in commercial buildings.

In residential buildings the amount of electricity consumption was greatest for appliances, while in commercial buildings lighting consumption was greatest. Space heating was the major consumer of natural gas in both residential and commercial buildings.

Copies of the report are available from the U.S. Government Printing Office (202/512-1800), or through EIA's National Energy Information Center (202/586-8800). (EIA Press Release EIA-95-14, June 29,1995 .)

\section{EIA Provides Overview of Global Energy Markets}

A new Energy Information Administration (EIA) publication profiles 26 major energy producing or consuming countries, including newly emerging markets in Central and Southeast Asia. The report summarizes, in a concise and easy-to-read fashion, many of the dramatic developments that took place in world energy markets in 1994, from the opening up of the vast energy potential of the former Soviet Republics to large-scale power and privatization projects in India and China.

The report, Country Analysis Briefs: 1994, is available from the U.S. Government Printing Office (202/512-1800). The information from the report can also be accessed electronically through EIA's Home Page on the Internet. To locate EIA's Home Page, open the Uniform Resource Locator named: http://www.eia.doe.gov, using a hypertext viewer such as Mosaic or Netscape. The various country briefs can then be viewed and printed directly. 


\section{DISCLAIMER}

This report was prepared as an account of work sponsored by an agency of the United States Government. Neither the United States Government nor any agency thereof, nor any of their employees, make any warranty, express or implied, or assumes any legal liability or responsibility for the accuracy, completeness, or usefulness of any information, apparatus, product, or process disclosed, or represents that its use would not infringe privately owned rights. Reference herein to any specific commercial product, process, or service by trade name, trademark, manufacturer, or otherwise does not necessarily constitute or imply its endorsement, recommendation, or favoring by the United States Government or any agency thereof. The views and opinions of authors expressed herein do not necessarily state or reflect those of the United States Government or any agency thereof. 


\section{DISCLAIMER}

Portions of this document may be illegible in electronic image products. Images are produced from the best available original document. 


\section{EIA Releases International Forecasting Data Report \\ (continued from page 1)}

countries is expected to exceed that of the OECD countries by 2010 .

The largest gains in energy consumption are expected in the non-OECD Asia region, led by countries experiencing rapid economic expansion, such as China and India. In non-OECD Asia, energy demand is expected to grow by 3.5 percent per year over the projection period. In contrast, in Eastern Europe and the former Soviet Union, little or no net growth is projected for energy consumption between 1990 and 2010, as these economies struggle to recover from their current turmoil.

Substantial declines (improvements) are projected for world energy intensity (a measure of energy consumption relative to the level of economic output). Energy intensity is projected to drop most rapidly in the developing non-OECD countries. However, alternative assumptions about energy intensity could have a significant impact on energy consumption projections presented in the Outlook. Were energy intensities in developing areas to remain constant at present levels, world energy requirements in 2010 could be as much as 92 quadrillion Btu higher than the Reference Case projections of 472 quadrillion Btu. If non-OECD energy intensity were to grow at its 1970-1992 rate through 2010, world energy demand could be 28 percent higher than in the Reference Case projections. Moreover, if non-OECD countries were to consume at the same per capita rate as OECD countries, consumption would be almost 469 percent higher than in the Reference Case projections.

Natural gas and renewable energy sources (hydroelectricity, geothermal, solar, wind, and other renewable resources) are expected to be the fastest growing energy sources over the projection period, at 2 and 2.3 percent per year, respectively.
The increase in natural gas use reflects efforts to reduce pollution and carbon emissions by switching to cleaner fuels. The rising demand for electric power in the non-OECD countries is one reason underlying the rapid growth of renewable energy use in the projections.

Copies of the report are available from the U.S. Government Printing Office (202/512-1800).

\section{Summer Driving Season Gasoline Prices, Consumption}

According to two reports released by the Energy Information Administration (EIA), summer 1995 (April through September) gasoline prices are projected to average $\$ 1.24$ per gallon, 5 cents higher than last year. The implementation of reformulated gasoline regulations, affecting nearly 30 percent of U.S. demand, accounts for between 1 cent and 2 cents of this increase. Due to continued improvements in fleet efficiency, average real (inflation-adjusted) fuel costs remain unchanged on a cost-per-mile basis.

EIA's Short-Term Energy Outlook and Summer 1995 Gasoline Assessment say that, for the 1995 summer driving season, motor gasoline demand is projected to average 7.9 million barrels per day, an increase of 140,000 barrels per day (or 1.8 percent) from that of the previous summer season. In the third quarter (July through September), average demand is projected to approach 8 million barrels per day, a 17-year high. Buoyed by increases in real personal disposable income, highway travel activity is projected to be 2.8 percent higher than last year. Fleet-wide fuel efficiencies are projected to be 1.0 percent higher than last summer, offsetting part of the effect of the increase in highway travel activity on consumption. Along with record demand, low preseason inventories, high refinery utilization, and reduced supply flexibility due to reformulated gasoline add uncertainties to the summer outlook.

The EIA also projects that the world oil price is not expected to rise much beyond the $\$ 17.50$-perbarrel mark through 1996. Several factors, including the failure of Iraq to agree to U.N. terms for limited oil exports, temporarily bolstered prices (continued on page 4) 


\section{Summer Driving Season (continued from page 3)}

in recent weeks. However, despite expected world oil demand increases in 1995 and 1996, sufficient production capacity exists both in and out of OPEC to maintain a rough balance in oil markets for at least the next 2 years.

Other statistics from the EIA quarterly report Short-Term Energy Outlook include:

- Petroleum net imports' share of U.S. demand is expected to creep to within a percentage point of the 50-percent mark in 1996, as U.S. petroleum demand is projected to increase by 0.6 percent in 1995, and by another 2.6 percent in 1996.

* Demand for natural gas is expected to continue to grow through the forecast period. Total gas demand is projected to reach 21.3 trillion cubic feet in 1995, a 3.4percent increase. In 1996, gas demand is expected to grow more slowly, along with the economy. Limits to gas demand growth stemming from the slower growing economy should keep wellhead gas prices well below $\$ 2$ per thousand cubic feet, except during peak demand months.

Electricity demand is expected to continue to rise steadily across all sectors during the forecast period. Normal weather assumptions imply a temporary boost to demand in mid-to-late 1995 and early 1996.

* Growing demand for electricity leads to a 1.9-percent increase in coal use by electric utilities and nonutility power producers in 1995. Coal use for electricity generation is projected to grow by an additional 2.9 percent in 1996. Over the forecast period, coal-fired generation accounts for approximately 52 percent of electricity produced by electric utilities and nonutilities combined.

Copies of the Short-Term Energy Outlook are available from the U.S. Government Printing Office (202/512-1800) or through EIA's National Energy Information Center (202/586-8800). (EIA Press Release EIA-95-11, May 12, 1995)

\section{EIA Details Changes in Household Energy Use}

Lifestyle changes are creating new patterns of appliance and overall energy usage in U.S. homes, according to a report released by the Energy Information Administration (EIA). Personal computers, microwave ovens, electric clothes dryers, window/ceiling fans, and two or more color television sets are found in more and more households.

Housing Characteristics 1993 presents the results of the ninth survey of energy consumption in the residential sector conducted by the EIA since 1978. The Residential Energy Consumption Survey provides a comprehensive look at the lifestyle patterns of American households, the physical features of their housing units, and the stocks of appliances as they all relate to the consumption of energy.

Data on 36 home appliances (in addition to main heating equipment) are now collected. Appliances surveyed for the first time include toaster ovens, heated aquariums, air cleaners, laser printers for home computers, facsimile machines, photocopiers, halogen lamps, compact fluorescent lamps, point-of-use water heaters, and heat pump water heaters.

Some overall trends indicated by the report are that personal computers are now found in 23 percent of all homes, an increase from 16 percent 3 years earlier; microwave ovens are currently found in 84 percent of all homes, but one-half are only used for snacks, defrosting, or reheating foods-not for cooking meals; overall, two-thirds of U.S. households used air-conditioning in 1993 (unchanged from 1990), but more households used central air-conditioning and fewer used wall/window units in 1993 than in 1990.

\section{A second report, Household Energy Consumption and Expenditures 1993, presenting data on the amount and costs of energy used for appliances, space heating, air conditioning, water heating, and lighting, will be available in October.}

Copies of Housing Characteristics 1993 are available from the U.S. Government Printing Office (202/512-1800) or through EIA's National Energy Information Center (202/586-8800) 
Reprints of special features (Feature Articles, Highlights, Energy Previews, EIA Data News, etc.) appearing in Energy Information Administration (EIA) reports are available free from the National Energy Information Center.
Below is a listing of the features published so far in 1995. For a listing of features published in 1994, please refer to the November-December issue of EIA New Releases, DOE/EIA-0204(94/06). to

\section{Reature (Publication)}

Highlights: Manufacturing Consumption of Energy 1991 (Monthly Energy Review)

Feature Article: U.S. Wind Energy Potential: The Effect of the Proximity of Wind

Resources to Transmission Lines (Monthly Energy Review)

Feature Article: The Comparability of Resource and Reserve Data for Crude Oil,

Natural Gas, Coal, and Uranium (Natural Gas Monthly and Petroleum Supply Monthly)

EIA Data News: The Response Analysis Survey: Evaluating Manufacturing Energy

Consumption Survey Methodology (Monthly Energy Review)

Feature Article: Comparisons of Independent Statistics on Petroleum Supply

(Petroleum Supply Monthly)

Highlights: Commercial Buildings Energy Consumption and Expenditures 1992

(Monthly Energy Review)

Energy Preview: Electric Utility Fleet Survey 1993, Preliminary Estimates

(Monthly Energy Review)

Feature Article: Summer 1995 Gasoline Assessment (Petroleum Marketing Monthly and Petroleum Supply Monthly)

Feature Article: Summer Outlook for Motor Gasoline (Short-Term Energy

Outlook, Quarterly Projections, Second Quarter)

Feature Article: The Comparability of Resource and Reserve Data

for Crude Oil, Natural Gas, Coal, and Uranium (Quarterly Coal

Report October-December 1994, Fourth Quarter)

Feature Article: What Drives Motor Gasoline Prices? (Petroleum Marketing Monthly)
Publistied Date

January 1995

February 1995

March 1995

March 1995

April 1995

April 1995

April 1995

May 1995

May 1995

May 1995

June 1995

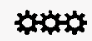

Periodically, the Energy Information Administration (EIA) issues press releases on current, highinterest issues. Copies of these releases are available from NEIC (202/586-8800).
Below is a listing of all EIA press releases prepared by EIA since the beginning of 1995 . For a listing of all 1994 press releases, see EIA New Releases, DOE/EIA-0204(94/06).

\section{Press Rel lease Title}

Full Report Assesses the Oil and Gas Resources of Fergana

Basin, Former Soviet Union

Improved Technology Leads to Lower Energy Price Projections

Internet, Bulletin Board Speed Access to ELA's Short-Term

Energy Model

Major Energy Companies' Strategies After Arab Oil Embargo

Shift from Growth to Consolidation

Reliability and the Changing Electric Power Industry

Natural Gas Wellhead Prices Expected To Remain Low in First Half 1995

EIA Examines the Decommissioning of the U.S. Uranium

Production Facilities

EIA Updates Reference on U.S. Coal

EIA Examines the Growing Importance of Longwall Mining

(continued on next page)

\section{Nimber}

Date Issued

$\begin{array}{ll}\text { EIA-95-02 } & 01 / 13 / 95 \\ \text { EIA-95-03 } & 01 / 26 / 95\end{array}$

EIA-95-04

$01 / 31 / 95$

EIA-95-05

$02 / 01 / 95$

EIA-95-06

$02 / 15 / 95$

EIA-95-07

$02 / 23 / 95$

EIA-95-08

EIA-95-09
$02 / 27 / 95$ $03 / 23 / 95$ 
EIA Provides a Nation-by-Nation Overview of Global Energy Markets

EIA-95-10

EIA-95-11

EIA-95-12

During Summer Driving Season

OPEC Supply of World Oil Projected To Rise to 52 Percent by 2010;

Electricity Use To Drive Growth in World Energy Demand

EIA Details Changes in Household Energy Use

Building Space, Use of Home Appliances Grew Rapidly in the 1980's
EIA-95-13

EIA-95-14
$05 / 11 / 95$

$05 / 12 / 95$

$06 / 14 / 95$

$06 / 12 / 95$

$06 / 29 / 95$

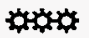

\section{Visit EIA on the Internet!}

The Energy Information Administration (EIA), world wide leader in energy data, analysis, and forecasting, is now providing access to EIA data on the Internet at the following sites:

World Wide Web: http://www.eia.doe.gov Gopher: gopher:/gopher.eia.doe.gov FTP: ftp://ftp.eia.doe.gov

These sites contain information on energy consumption, production, and prices; statistical, economic, and other analyses related to the energy sector; short-term (8 quarters) and midterm (15-20 years) forecasts of energy supply, demand, and prices; and other factors relating to the energy sector.

For example, users can now download EIA's Short-Term Energy Model to make projections on their own PC's; review financial information for the Nation's largest energy firms and electric utilities; download databases that provide energy data and profiles of the world's energy-producing countries; explore the "Oil and Gas Information Resource System," a public database system containing more than 10,000 time series on crude oil, petroleum products, oil and natural gas production, consumption, imports, exports, and prices; or use a query system to search for energy consumption data for individual states.

The EIA is continually adding new items to its Internet site and updates the data frequently (check our Web site periodically for new and updated products). For information on update cycles and new products, contact the National Energy Information Center at (202)586-8800; fax, (202)586-0727; e-mail, infoctr@eia.doe.gov.

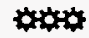

This report was prepared by the Energy Information Administration, the independent statistical and analytical agency within the U.S. Department of Energy. The information contained herein should not be construed as advocating or reflecting any policy position of the U.S. Department of Energy or of any other organization.

EIA New Releases is published six times per year and is available free of charge to anyone who requests it. Ask to be added to our mailing list by using the order form on the last page, by calling the EIA's National Energy Information Center (NEIC) on (202)586-8800 (open 9 a.m. to 5 p.m., Monday through Friday, eastern time), or by contacting us on Internet. Our e-mail address is:

\section{infoctr@eia.doe.gov.}

This report is also available electronically from the following:

EPUB, EIA's electronic bulletin board (see page 8 for access information)

EIA's World Wide Web site for Internet users (http://www.eia.doe.gov)

Inquiries or comments concerning the contents of this publication should be directed to the chief editor Ingrid Springer at (202)5861100; all questions about EIA information should be directed to NEIC.

\section{Do You Want To Test EIA's CD-ROM?}

The EIA has begun development of a periodical CD-ROM that will contain the bulk of EIA's publications, applications, and databases. To participate in a test of a trial copy later this summer, contact the National Energy Information Center by e-mail at infoctr@eia.doe.gov.

Future issues of this newsletter will provide updates on the status of the CD-ROM. 


\section{Microfiched Model and System} Documentation

The Energy Information Administration (EIA) model and system documentation reports are available in microfiche form; the agency does not formally print or distribute this category of reports. The Department of Energy's Office of Scientific and Technical Information (OSTI) in Oak Ridge, Tennessee, produces these reports in microfiche form and sends the microfiche to the
National Technical Information Service (NTIS). NTIS sells these documents in microfiche or hard-copy form upon request.

Following is a listing of all EIA reports that have been released to OSTI since the beginning of 1995. Future editions of EIA New Releases will provide updates on the latest available reports. For more information, contact the National Energy Information Center (NEIC) by telephone on (202)586-8800 or on Internet (infoctr@eia.doe.gov). \%

\section{Trite}

\section{DOE Namber}

Released io OSTI:

Model Documentation, Natural Gas Transmission and Distribution Model (NGTDM) of the National Energy Modeling System, Volume II: Model Developer's Report

Documentation of the Petroleum Market Model (PMM) Appendix: Model Developer's Report

Model Documentation, Renewable Fuels Module of the National Energy Modeling System, Appendix: Model

Performance

Documentation of the Oil and Gas Supply Module (OGSM) Appendix: Model Developers Report

Model Developer's Appendix to the Model Documentation Report: NEMS Macroeconomic Activity Module

Model Documentation Report: Residential Sector Demand Module of the National Energy Modeling System

Model Documentation Natural Gas Transmission and

Distribution Model of the National Energy Modeling System, Volume I

Model Documentation Electricity Market Module Modifications to the Electricity Capacity

Planning Submodule

Model Documentation Coal Market Module of the National Energy Modeling System

NEMS Integrating Module Documentation Report Documentation of the Electricity Market Module (EMM) Appendix: Model Developers Report
DOE/EIA-M062/2

January 1995

DOE/EIA-M059/A

January 1995

DOE/EIA-M069/A

January 1995

DOE/EIA-M063A(95)

March 1995

DOE/EIA-M065A(95)

March 1995

DOE/EIA-M067(95)

March 1995

DOE/EIA-M062/1(95)

March 1995

DOE/EIA-M068-B/1

April 1995

DOE/EIA-M060(95)

April 1995

DOE/EIA-M057(95)

May 1995

DOE/EIA-M068(95)Appx. 


\section{Electronic Publishing System BIT B}

EPUB is an electronic publishing system maintained by the Energy Information Administration (EIA) of the U.S. Department of Energy. EPUB allows the general public to electronically access selected energy data from many of EIA's statistical reports. The system is a menu-driven, bulletin-board-type system with extensive online help capabilities that can be accessed free of charge 24 hours a day by using a terminal or PC with an asynchronous modem. (EPUB will be taken down briefly at midnight for backup.)

PC users must provide the following information to their communications software in order to successfully access the EPUB system:

Communications Parameters:

Baud Rate: Up to 28,800 bps

Data Bits: 8 ; Stop Bits: 1

Parity: None; Duplex: Full

Terminal Type: ANSI, ANSI-BBS, VT100, etc.

Once communications software and/or hardware have been configured, EPUB can be accessed by dialing (202)586-2557. When a connection to the system has been made, some users may find that the menu-driven instructions and the online capabilities will provide enough information to effectively use EPUB. More information may be obtained from:

National Energy Information Center, EI-231

Energy Information Administration

Forrestal Building, Room 1F-048

Washington, DC 20585

(202)586-8800

Internet E-Mail: infoctr@eia.doe.gov

TTY: For people who are deaf or

hard of hearing: (202)586-1181

Hours: 9 a.m. to 5 p.m., M-F, eastern time
For communications or technical assistance, call (202)586-8959, 8 a.m. to 5 p.m. eastern time, Monday through Friday. For questions about the contents of EPUB reports and data, call (202)5868800,9 a.m. to 5 p.m., Monday through Friday, eastern time.

Following is a listing of some of the data and reports that are provided on EPUB:

Heating fuel data (April through September) Updated the second week of the month.

Oxygenate data

Updated approximately the 25th of the month.

Weekly Petroleum Status Report

Updated on Wednesda's's (Thursdays in the event of a holiday) at 9 a.m.

Petroleum Supply Monthly

Updated between the 23rd and 26th of the month.

Petroleum Marketing Monthly

Updated on the 20th of the month.

Natural Gas Monthly

Updated on the 20th of the month.

Weekly Coal Production

Updated on Fridays at 5 p.m.

Quarterly Coal Report

Updated 60 days after the end of the quarter.

Electric Power Monthly

Updated during the first week of the month.

Monthly Energy Review

Updated the last week of the month.

Short-Term Energy Outlook

Updated 60 days after the end of the quarter.

Winter Fuels Report (October through April) Propane inventory data updated Wednesdays at 5 p.m. All other data updated Thursdays (Friday in event of a holiday) at 5 p.m.

\section{Internet Access to EPUB}

The EPUB system is not as yet directly accessible via Internet. However, Internet users can access EPUB via the FEDWORLD electronic bulletin board operated by the National Technical Information Service, Department of Commerce. The Internet address for FEDWORLD is <FEDWORLD.GOV>. Select "GATEWAY" from the main menu, and EPUB will be item 16 on that list. 


\section{Multisource Energy}

\section{Monthly Energy Review}

This top-selling monthly publication presents a complete overview of the Nation's energy picture. It provides data on petroleum, natural gas, coal, electricity, nuclear energy, oil and gas resource development, prices, consumption, and the international energy situation. Appendices present thermal, metric, and other physical conversion factors.

DOE/EIA-0035(95/05), 180 PP., May 1995 DOE/EIA-0035(95/06), 180 Pp., June 1995

Annual Subscription:

Domestic, $\$ 80.00$; Foreign, $\$ 100.00$

Single Issue: Domestic, \$12.00; Foreign, $\$ 15.00$

\section{Short-Term Energy Outlook Quarterly Projections}

This report discusses macroeconomic activities; the outlook for petroleum demand, supply, and product prices; world oil prices; and outlooks for other major energy sources (natural gas, coal, and electricity).

The forecast period for this issue extends from the second quarter of 1995 through the fourth quarter of 1996. Values for the first quarter of 1995, however, are preliminary EIA estimates.

DOE/EIA-0202(95/2Q), 60 pp., May 1995

Annual Subscription:

Domestic, \$17.00; Foreign, \$21.25

Single Issue: Domestic, \$4.75; Foreign, \$5.94

\section{International Energy Outlook 1995}

This report presents an assessment of the international energy market outlook through 2010 and looks at the worldwide trends associated with energy consumption. The historical time frame for energy consumption and carbon emissions has been expanded from previous reports to incorporate data from 1970; the longer time span provides readers with a better historical context for the projections. Regional consumption projections for oil, natural gas, coal, nuclear power, hydroelectric and other renewable energy, and electricity are discussed.

DOE/EIA-0484(95), 108 pp., May 1995

GPO Stock No. 061-003-00911-5

Domestic, $\$ 7.00$; Foreign, $\$ 8.75$
International Energy Annual 1993

This report presents an overview of key international energy trends for production, consumption, imports, and exports of primary energy commodities in over 200 countries, dependencies, and areas of special sovereignty. Also included are population and gross domestic product data, as well as prices for crude oil and petroleum products in selected countries.

Renewable energy data presented in the report include hydroelectric power, geothermal, solar, and wind electric power and alcohol for fuel.

DOE/EIA-0219(93), 168 pp., May 1995

GPO Stock No. 061-003-00908-5

Domestic, $\$ 15.00$; Foreign, $\$ 18.75$

\section{Profiles of Foreign Direct Investment in U.S. Energy 1993} This report describes the role of foreign ownership in U.S. energy resources. The report also looks at the investment patterns of U.S. energy companies in other countries.

DOE/EIA-0466(93), 48 pp., May 1995

GPO Stock No. 061-003-00909-3

Domestic, \$3.25; Foreign, $\$ 4.06$

\section{State Energy Data Report 1993}

This report presents estimates of annual energy consumption at the State and national levels by major economic sector and by principal energy type for 1960, 1965, and 1970 through 1993.

DOE/EIA-0214(93), 528 pp., June 1995

GPO Stock No. 061-003-00917-4

Domestic, $\$ 33.00$; Foreign, $\$ 41.25$

\section{Annual Energy Review 1994}

This report presents EIA's historical energy data for major energy activities, including consumption, production, trade, and stocks for all major energy commodities. For most series, statistics are given for every year from 1949 through 1994.

DOE/EIA-0384(94), 416 pp., June 1995

GPO Stock No. 061-003-00919-1

Domestic, \$25.00; Foreign, \$31.25 


\section{Petroleum}

\section{Weekly Petroleum Status Report}

This weekly report, published each Wednesday, provides timely data on petroleum supply and disposition (includes propane stocks). The data are based on company submissions for the week ending at 7 a.m. the preceding Friday.

DOE/EIA-0208(95-18)-(95-26) varied page count

May through June 1995

Annual Subscription:

Domestic, $\$ 65.00$; Foreign, $\$ 81.25$

Single Issue: Domestic, \$3.50; Foreign, \$4.38

\section{International Petroleum Statistics Report}

This report contains current international data on oil production, consumption, imports, exports, and stocks.

DOE/EIA-0520(95/05), 84 pp., May 1995

DOE/EIA-0520(95/06), 84 Pp., June 1995

Annual Subscription:

Domestic, \$52.00; Foreign, $\$ 65.00$

Single Issue: Domestic, \$5.50; Foreign, \$6.88

\section{Petroleum Marketing Monthly}

This publication provides price information on a variety of petroleum products, including motor gasoline, distillate fuel oil, jet fuels, kerosene, and propane. Sales data for petroleum products are also included.

DOE/EIA-0380(95/05), 220 pp., May 1995

DOE/EIA-0380(95/06), 224 pp., June 1995

Annual Subscription:

Domestic, $\$ 84.00$; Foreign, $\$ 105.00$

Single Issue: Domestic, \$14.00; Foreign, $\$ 17.50$

NOTE: In some instances, the month shown here may not correspond with the month shown on the cover or spine of a report. EIA New Releases lists the month that a report is RELEASED to the printer. However, some EIA report covers and spines display the date when the report is AVAILABLE to the public.

\section{Petroleum Supply Monthly}

This publication provides monthly statistics on petroleum supply, disposition, production, refinery operations, stocks, and transport.

DOE/EIA-0109(95/05), 184 pp., May 1995

DOE/EIA-0109(95/06), 168 pp., June 1995

Annual Subscription:

Domestic, \$83.00; Foreign, $\$ 103.75$

Single Issue: Domestic, $\$ 12.00$; Foreign, $\$ 15.00$

\section{Petroleum Supply Annual 1994 \\ Volumes 1 and 2}

Volume 1 contains information on the supply and disposition of crude oil and petroleum products and presents summary and detailed statistics and refinery and oxygenate capacity, each with final annual data.

Volume 2 presents final statistics for each month of 1994 and replaces data previously published in the Petroleum Supply Monthly.

DOE/EIA-0340(94)/1, 192 pp., May 1995 (Volume 1)

GPO Stock No. 061-003-00910-7

Domestic, \$14.00; Foreign, \$17.50

DOE/EIA-0340(94)/2, 608 pp., June 1995 (Volume 2)

GPO Stock No. 061-003-00913-1

Domestic, $\$ 39.00$; Foreign, $\$ 48.75$

\section{Electricity}

\section{Electric Power Monthly}

This report presents comprehensive monthly statistics at the national, Census division, State, and U.S. levels for net generation, fossil fuel consumption and stocks, quantity, quality, and cost of fossil fuels, electricity sales, revenue, and average revenue per kilowatthour of electricity sold.

DOE/EIA-0226(95/05), 204 pp., May 1995

DOE/EIA-0226(95/06), 204 Pp., June 1995

Annual Subscription:

Domestic, \$87.00; Foreign, $\$ 108.75$

Single Issue: Domestic, \$14.00; Foreign, $\$ 17.50$ 


\section{Coal Reports}

\section{Weekly Coal Production}

This short report provides timely information on coal production, as estimated by the EIA from railroad car loadings.

DOE/EIA-0218(95-17)-(95-25), varied page count May through June 1995

Annual Subscription:

Domestic, $\$ 85.00$; Foreign, $\$ 106.25$

Single Issue: Domestic, $\$ 2.00$; Foreign, $\$ 2.50$

\section{Quarterly Coal Report \\ October-December 1994}

This report provides information about U.S. coal production, distribution, exports, imports, receipts, prices, consumption, and stocks. Also provided are coke production, consumption, distribution, and imports and exports data.

DOE/EIA-0121(94/4Q), 184 pp., May 1995

Annual Subscription:

Domestic, $\$ 26.00$; Foreign, $\$ 32.50$

Single Issue: Domestic, \$11.00; Foreign, \$13.75

\section{Energy Consumption}

\section{Housing Characteristics 1993}

This report presents statistics about the energyrelated characteristics of U.S. households. The data used in preparation of the report were collected in the 1993 Residential Energy Consumption Survey (RECS)-the ninth in a series of nationwide energy consumption surveys conducted since 1978 by the EIA.

DOE/EIA-0314(92), 376 pp., May 1995

GPO Stock No. 061-003-00912-3

Domestic, $\$ 23.00$; Foreign, $\$ 28.75$

\section{Buildings and Energy in the 1980's}

This is the first report to provide a unified vision of energy use in residential and commercial buildings; it presents energy data that are consistent between the two sectors and across the decade of the 1980 's.

DOE/EIA-0555(95)/1, 108 pp., June 1995

GPO Stock No. 061-003-00914-0

Domestic, $\$ 6.50$; Foreign, $\$ 8.13$

\section{Metadata}

\section{Energy Information Sheets}

This report was developed to provide general information on various energy-related topics.

DOE/EIA-0578(93), 52 pp., June 1995

Call the National Energy Information Center (NEIC) on (202)586-8800 to request a free copy.

\section{U.S. Energy Industry Financial Developments 1995 First Quarter}

This report provides information on the financial performance of energy companies during the most recent reporting period.

DOE/EIA-0543(95/1Q), 28 pp., June 1995

Single Issue: Domestic, $\$ 3.00$; Foreign, $\$ 3.75$

Please note that this is the last published issue-future issues will be available on the Internet at http://www.eia.doe.gov. Also, highlights of the report will be printed on a quarterly basis in EIA's Short-Term Energy Outlook.

\section{EIA Directory of Electronic Products, First Quarter 1994} This directory lists EIA's latest machine-readable data files and computer models and provides information about online files and compact discs.

DOE/EIA-0569(5/1Q), 84 pp., June 1995 The directory is free from NEIC (202/5868800).

\section{Natural Gas}

\section{Natural Gas Monthly}

This report provides information on the supply and disposition of natural gas, including production, storage, import, export, and consumption data and provides information on the activities of major interstate pipeline companies.

DOE/EIA-0130(95/05), 112 pp., May 1995 DOE/EIA-0130(95/06), 120 pp., June 1995 Annual Subscription: Domestic, $\$ 77.00$; Foreign, $\$ 96.25$ Single Issue: Domestic, $\$ 8.00$; Foreign, $\$ 10.00$ 
The Energy Information Administration (EIA) makes its machine-readable data files and modeling programs available through the National Technical Information Service (NTIS) (703)4874650. For a description of EIA's machine-readable products, contact the National Energy Information Center (NEIC) at (202)586-8800 (Internet E-Mail: infoctr@eia.doe.gov) and request a copy of the EIA Directory of Electronic Products.
Data and model diskettes are available from the Department of Energy's Office of Scientific and Technical Information (OSTI). To order, call OSTI at (615)576-8401 and reference the diskettes by title.

Listed below are the most recently updated data files made available from NTIS and OSTI. wat

NTIS

\begin{tabular}{|c|c|c|c|}
\hline Mumber. & Mrequency & T116 & Pater or \\
\hline PB93-592450 & Monthly & Monthly Power Plant Report (diskette) & $01 / 95-03 / 95$ \\
\hline PB91-591650 & Monthly & Monthly Energy Review Data Base (diskette) & 1973-05/95 \\
\hline PB93-592460 & Monthly & $\begin{array}{l}\text { Monthly Electric Utility Sales and Revenue Report } \\
\text { (diskette) }\end{array}$ & $01 / 95-03 / 95$ \\
\hline PB95-* & Annual & State Energy Data Report (diskette) & 1960-1993 \\
\hline PB95-* & Quarterly & Short-Term Energy Model & $1995 / 2 Q$ \\
\hline
\end{tabular}

*Order number not available yet.

OSTI (Diskettes)

\begin{tabular}{|c|c|c|}
\hline Wreguningy & Tine & Pates of \\
\hline Monthly & Monthly Energy Review Data Base & 1973-05/95 \\
\hline Monthly & Monthly Power Plant Report & $01 / 95-03 / 95$ \\
\hline Monthly & Monthly Electric Utility Sales and Revenue Report & $01 / 95-03 / 95$ \\
\hline Annual & State Energy Data Report & 1960-1993 \\
\hline Quarterly & Short-Term Energy Model & $1995 / 2 Q$ \\
\hline
\end{tabular}

For a complete listing of the Energy Information Administration's (EIA) reports published in 1994, refer to EIA's Annual Report to Congress 1994. It is available, free of charge, from the National Energy Information Center at the following address and numbers:

\section{National Energy Information Center \\ Energy Information Administration \\ EI-231, Forrestal Building \\ Washington, DC 20585 \\ (202)586-8800 \\ Internet E-Mail: infoctr@eia.doe.gov \\ TTY: (202)586-1181 \\ Hours: 9 a.m. to 5 p.m., M-F, eastern time. A}

Please note that prices of EIA products sold by the U.S. Government Printing Office, the National Technical Information Service, or the Office of Scientific and Technical Information are subject to change without prior notice. 
Items listed in EIA New Releases can be ordered from one of four places: the National Energy Information Center (NEIC), the U.S. Government Printing Office (GPO), the National Technical
Information Service (NTIS), and the U.S. Department of Energy's Office of Scientific and Technical Information (OSTI). The chart below shows what can be ordered and from where.

\section{H1. P.}

NEIC

女

Directories and EIA New Releases - current issues

Directories and EIA New Releases - back issues

For-sale publications - current issues

For-sale publications - back issues

Subscriptions

Machine-readable products

The category of publications called "Directories and EIA New Releases" is free to everyone. The category includes the following items: EIA New Releases, Energy Information Directory, EIA Directory of Electronic Products, EIA Publications Directory, Directory of Energy Data Collection Forms, Directory of Energy Information Model Abstracts, the Energy Information Administration's Annual Report to Congress, and all service reports and Energy Information Sheets. However, there is a charge for back issues from NTIS. (A current issue is one that is less than 1 year old.)

Publications and subscriptions normally for sale are free if ordered from NEIC by the following customers: Public, school, and university libraries; DOE contractors; employees of the media, Congress, and Federal, State, local, and foreign governments; and EIA survey respondents.

Subscriptions from GPO are available for weekly, monthly, and quarterly, but not for annual, publications.

\section{To Order from NEIC}

Contact us at (202)586-8800, TTY (202)586-1181, Internet E-Mail: infoctr@eia.doe.gov, or use the form entitled "NEIC Orders" in the back of this report. This form should also be used if you have changed your address or if you want your name removed from the mailing list.

\section{To Order from GPO}

Single-Issue Publications and Subscriptions: Call the GPO Main Order Desk at (202)512-1800 (FAX: (202)512-2250) or use the order form entitled "GPO Orders" in the back of this report.
GPO accepts the following types of payment: check or money order made out to the Superintendent of Documents, credit card number and expiration date for VISA or MasterCard, or a GPO deposit account number. To open such an account, call (202)783-3238. Payment must be included before an order can be filled.

\section{To Order from OSTI}

Personal Computer Diskettes:

Call Request Services at (615)576-8401 or send your order to the following address: Office of Scientific and Technical Information, Request Services, P.O. Box 62, Oak Ridge, TN 37831.

OSTI accepts the following types of payment: check or money order made out to the United States Department of Energy, or credit card number and expiration date for VISA or MasterCard. Payment must be included before an order can be filled.

\section{To Order from NTIS}

To order from NTIS, call (703)487-4650 or use the order form entitled "NTIS Orders" in the back of this report.

Reports are available from NTIS in hard copy, microfiche, or paper copy reproduced from microfiche.

NTIS accepts the following forms of payment: check or money order made out to NTIS, VISA, MasterCard, or American Express, or an NTIS deposit account number. To open an NTIS deposit account, call (703)487-4770. Requests will not be processed unless payment accompanies the order, except in the case of "ship-and-bill" orders. 


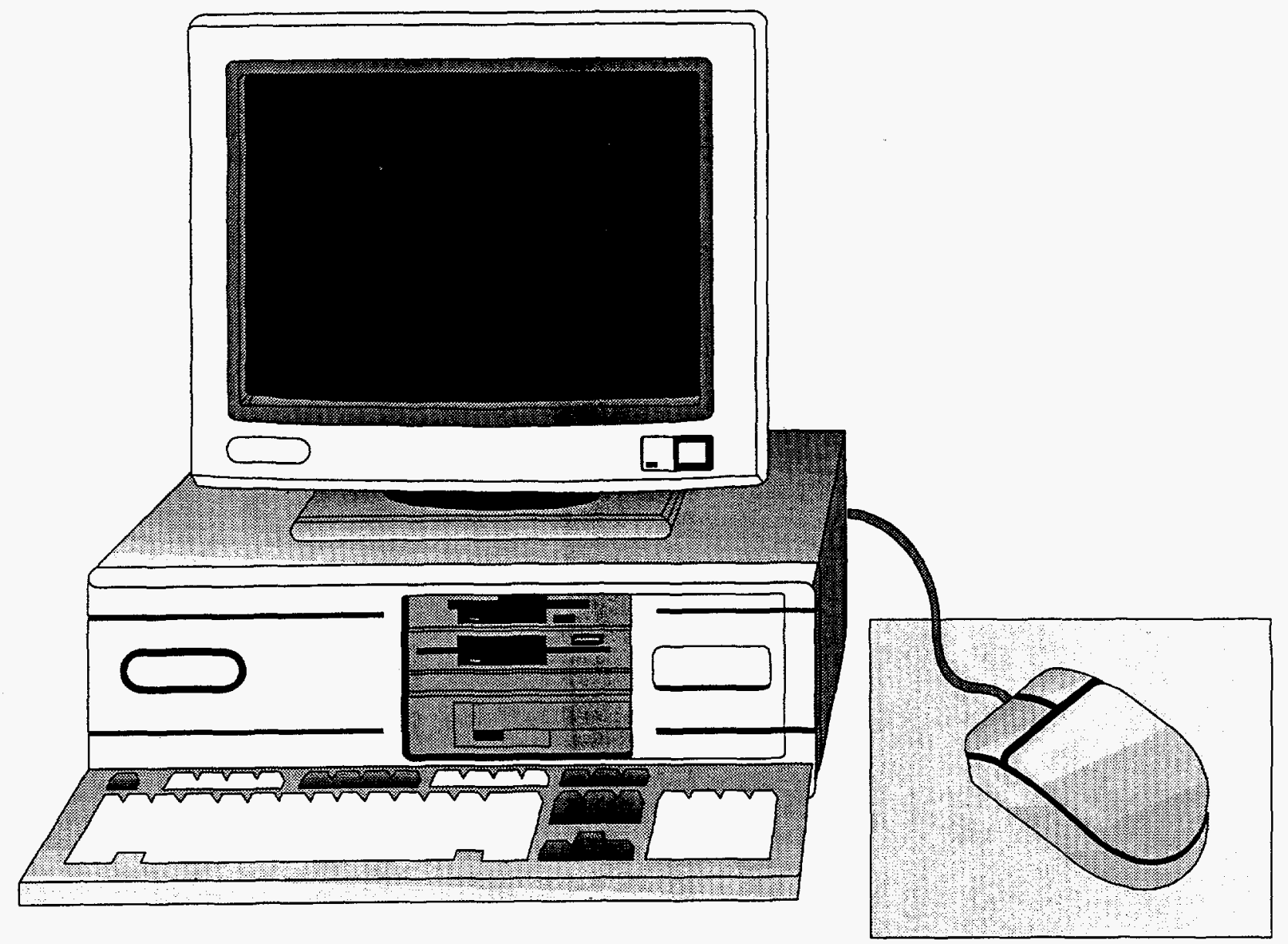

RECS Data on Diskettes

The public use data for the 1993 Residential Energy Consumption Survey RECS) are available on diskette.

-For IBM-PC and compatible microcomputers

-3-1/2 inch double-sided, high-density diskette

-Flat ASCll format

-Dbase format

- Contains a READ.ME DOS text file

-Technical document file

For ordering information contact:

Office of Scientific and Technical Information (OSTI)

P.O. Box 62

Oak Ridge, TN 37831

(615) 576-8401

National Technical Information Service 5285 Port Royal Road

Attention: Order Control

Springfield, VA 22161

(703) $487-4650$ 
All telephone numbers are in area code 202, except where noted otherwise. Each FAX number applies to all names that follow. Each Internet name is followed with @eia.doe.gov

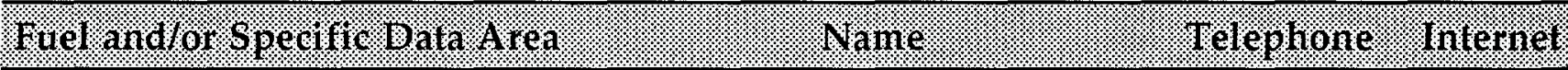

COAL:

Annual Mining and Production

Consumption

Distribution

Exports

Monthly Data

Producer/Distributor Stocks

Production and Consumption

Quarterly Data

Reserves

Short-Term Coal Projections

Stocks

Weekly Production

\section{ELECTRIC POWER: Nonutility}

Capacity, Generation, Fuel Consumption, and Sales to Grid

Generation

Renewable Energy Use

Short-Term Nonutility Sales Projections

ELECTRIC POWER: Utility

Demand-Side Management

Emissions

Utility Boiler Design

Utility Bulk Power Transmission

Utility Capacity

Utility Repowering

Utility Life Extension

Utility Financial Data Systems

Utility Finance, Investor-Owned

Utility Finance, Publicly Owned

Utility Fuel Consumption

Utility Fuel Receipts

Utility Fuel Cost and Quality

Utility Fuel Stocks/Generation

Utility Power Production Expenses

Short-Term Hydroelectric Power Projections

Short-Term Electricity Imports Projections

\begin{tabular}{lll} 
FAX Number: & $254-5765$ & \\
\hline Fred Freme & $254-5367$ & ffreme \\
Steve Scott & $254-5467$ & sscott \\
Mary Lilly & $254-5391$ & mlilly \\
Tom Murphy & $254-5561$ & tmurphy \\
Paulette Young & $254-5481$ & pyoung \\
Paulette Young & $254-5481$ & pyoung \\
Tom Murphy & $254-5561$ & tmurphy \\
Mary Paull & $254-5379$ & mpaull \\
Paulette Young & $254-5481$ & pyoung \\
Richard Bonskowski & $254-5383$ & rbonskow \\
Willie Hong & $254-5365$ & bhong \\
Mary Paull & $254-5379$ & mpaull \\
Mary Lilly & $254-5391$ & mlilly \\
& & \\
FAX Number: & $254-5765$ & \\
John Colligan & $254-5465$ & jcolliga \\
Betty Williams & $254-5656$ & bwilliam \\
Robin Reichenbach & $254-5353$ & rreichen \\
Larry Prete & $254-5671$ & lprete \\
Robin Reichenbach & $254-5353$ & rreichen \\
& & \\
FAX Number: & $254-5765$ & \\
\hline Linda Bromley & $254-5653$ & lbromley \\
John Colligan & $254-5465$ & jcolliga \\
John Colligan & $254-5465$ & jcolliga \\
John Makens & $254-5629$ & jmakens \\
Elsie Bess & $254-5637$ & ebess \\
Karen McDaniel & $254-5672$ & kmcdanie \\
Arthur Fuldner & $254-5321$ & afuldner \\
Arthur Fuldner & $254-5321$ & afuldner \\
Lucinda Gilliam & $254-5438$ & lgilliam \\
Jerry Sanderson & $254-5463$ & jsanders \\
C. Harris-Russell & $254-5437$ & charrisr \\
Deborah Bolden & $254-5663$ & dbolden \\
Melvin Johnson & $254-5665$ & mejohnso \\
Kenny McClevey & $254-5655$ & kmccleve \\
Kenny McClevey & $254-5655$ & kmccleve \\
Deborah Bolden & $254-5663$ & dbolden \\
Melvin Johnson & $254-5665$ & mejohnso \\
Elsie Bess & $254-5637$ & ebess \\
Robin Reichenbach & $254-5353$ & rreichen \\
Robin Reichenbach & $254-5353$ & rreichen \\
\hline
\end{tabular}

(Continued on next page.) 
All telephone numbers are in area code 202, except where noted otherwise.

Each FAX number applies to all names that follow.

Each Internet name is followed with @eia.doe.gov

\section{Fuel andor Specifrc Data Area \\ Electric Power: Utility (cont $\mathrm{d}$ ) \\ Statistical Reports}

Utility Sales and Revenue

NUCLEAR POWER:

Capacity and Generation

Domestic and Foreign Nuclear Power Capacity and Generation

Foreign Nuclear Power

Fuel Cycle Requirements Projections

Short-Term Nuclear Generation Projections

Spent Fuel Projections

Waste Characteristics

Waste Fund Fees

\section{URANIUM:}

Decommissioning

Demand/Requirements

Exploration and Industry Employment

Marketing, Imports/Exports

Production, Prices

Resources/Reserves

\section{RENEWABLE ENERGY:}

Alternative-Fueled Vehicles

Alternative Transportation Fuels

Biomass/Biofuels

Geothermal

Renewable Resources Assessment

Solar Collector, I'hotovoltaic

Solar Collector Cells/Modules

NATURAL GAS:

Coalbed Methane/Tight Gas

Consumer and City Gate Prices

Consumption (by sector)

Drilling

Exploration

Futures Market

Imports/Exports

Liquefied Natural Gas Storage

Natural Gas Liquids

Natural Gas Vehicles

Pipeline Capacity
Name

ieleptione: Internet.

FAX Number:

Sandra Smith

Deborah Bolden

Stephen Calopedis

Linda Bromley

FAX Number:

Doug Bonnar

Kenneth C. Wade

Doug Bonnar

William Liggett

Kenneth C. Wade

William Liggett

Kathy Gibbard

Jorge Luna-Camara

FAX Number:

Taesin Chung

William Liggett

Charles Johnson

Doug Bonnar

Doug Bonnar

Taesin Chung

FAX Number:

Jim Disbrow

Jim Disbrow

Robert Lowe

Peter Holihan

Mark Gielecki

Peter Holihan

Peter Holihan

FAX Number:

Bob King

Roy Kass

Roy Kass

Bob King

Dave Morehouse

John Herbert

Norm Crabtree

James Tobin

David Hinton

Rosemary Jameson

James Tobin
254-5765

254-5632

254-5663

254-5661

254-5653

254-5765

254-5560

254-5514

dbonner

kwade

254-5560 dbonner

254-5508 wliggett

254-5514 kwade

254-5508 wliggett

254-5559 kgibbard

254-5664 jlunacam

254-5765

254-5556

254-5508

254-5568

254-5560

254-5556

tchung

wliggett

cjohnson

dbonnar

dbonnar

tchung

254-5765

254-5558

254-5558

254-5557

254-5432

254-5320

254-5432

254-5432

jdisbrow

jdisbrow

rlowe

jholihan

mgieleck

jholihan

jholihan

586-1076

$586-4787$

$586-4790$

rking

nkass

$586-4790$

nkass

586-4787

rking

$586-4853$

dmorehou

$586-4360$

$586-6180$

586-4835

jherbert

ncrabtre

jtobin

586-2990

dhinton

586-6229

rjameson

$586-4835$ jtobin
$254-5560$ 
All telephone numbers are in area code 202, except where noted otherwise. Each FAX number applies to all names that follow. Each Internet name is followed with @eia.doe.gov

\begin{tabular}{|c|c|c|c|}
\hline Fiel andior specific Data Alrea & Vame & 1elephone. & Wintruet \\
\hline Natural Gas (cont d): & FAX Number: & $586-1076$ & \\
\hline Pricing Analysis & Mary Carlson & $586-4749$ & mcarlson \\
\hline Production & Donna Guerrina & $586-6135$ & dguerrin \\
\hline Productive Capacity & James Hicks & $\begin{array}{l}(214) 767-2200 / \\
\text { FAX: } 767-2204\end{array}$ & jhicks \\
\hline Regulatory Issues & Joan Heinkel & $586-4680$ & jheinkel \\
\hline Reserves & John Wood & $\begin{array}{c}(214) 767-2200 / \\
\text { FAX: } 767-2204\end{array}$ & jwood \\
\hline Resources & Dave Morehouse & $586-4853$ & dmorehou \\
\hline Rigs Count & Bob King & $586-4787$ & rking \\
\hline Spot Market & James Keeling & $586-6107$ & jkeeling \\
\hline Supply Analysis & James Tobin & $586-4835$ & jtobin \\
\hline Underground Storage & Rosemary Jameson & $586-6229$ & rjameson \\
\hline Wellhead Prices & Donna Guerrina & $586-6135$ & dguerrin \\
\hline PETROLEUM: Markets & FAX Number: & $586-5846$ & \\
\hline Crude Oil/Wellhead Value & Alan Griffith & $586-7225$ & agriffit \\
\hline Domestic Crude Oil First Purchase Report & Alan Griffith & $586-7225$ & agriffit \\
\hline Domestic Crude Oil Markets & Alan Griffith & $586-7225$ & agriffit \\
\hline \multirow[t]{2}{*}{ Domestic Products/Prices } & Charles Riner & $586-6610$ & criner \\
\hline & Kenneth Platto & $586-6364$ & kplatto \\
\hline Fuel Oil Sales & Alice Lippert & $586-9600$ & alippert \\
\hline Petroleum Demand Analysis & Charles Dale & $586-1805$ & cdale \\
\hline Petroleum Futures Market Analysis & Charles Dale & $586-1805$ & cdale \\
\hline Petroleum Inventory Analysis & Alan Griffith & $586-7225$ & agriffit \\
\hline Refineries/Acquisition Cost & Elizabeth Scott & $586-1258$ & escott \\
\hline PETROLEUM: Supply & FAX Number: & $586-5846$ & \\
\hline Crude Oil Production & David Hinton & $586-5994$ & dhinton \\
\hline Exports & John Nealey & $586-9670$ & jnealey \\
\hline Imports & Claudette Graham & $586-9649$ & cgraham \\
\hline Natural Gas Processing & David Hinton & $586-2990$ & dhinton \\
\hline Oxygenate Data & Irv Chamberlain & $586-9594$ & ichamber \\
\hline Propane Data & David Hinton & $586-2990$ & dhinton \\
\hline Refinery Operations & Evie Harper & $586-5786$ & eharper \\
\hline Stocks & Mike Conner & 586-1795 & mconner \\
\hline Supply and Disposition & Nancy Masterson & $586-8393$ & nmasters \\
\hline Transportation & Mike Conner & $586-1795$ & mconner \\
\hline Weekly Petroleum Status Report & Larry Alverson & $586-9664$ & lalverso \\
\hline OIL AND GAS: Production and Reserves & FAX Number: & $586-1076$ & \\
\hline Drilling and Rigs Count & Bob King & $586-4787$ & rking \\
\hline Production & Yousufuddin Mir & $\begin{array}{l}(214) 767-2200 / \\
\text { FAX: } 767-2204\end{array}$ & myousufu \\
\hline Resources & Dave Morehouse & $586-4853$ & dmorehou \\
\hline
\end{tabular}

(Continued on next page.) 
All telephone numbers are in area code 202, except where noted otherwise.

Each FAX number applies to all names that follow.

Each Internet name is followed with @eia.doe.gov

\section{Fiel andor specific. Oata 4 rea}

OIL AND GAS: Production and Reserves (cont'd)

Reserves

MULTIFUEL: Consumption

Commercial Buildings Sector Characteristics, Consumption, and Expenditures

Commercial Buildings Sector Analysis of Consumption and Conservation Trends

Integrated Historical Data

Manufacturing Sector Characteristics, Consumption and Expenditures

Manufacturing Sector Analysis of Consumption and

Conservation Trends

Residential Sector Characteristics, Consumption and Expenditures

Residential Sector Analysis of Consumption and Conservation Trends

Residential Transportation Sector Characteristics,

Consumption, and Expenditures

Residential Transportation Sector Analysis of Consumption and Conservation Trends

State-Level Consumption, Prices, and Expenditures

Transportation Program Development Related to Alternative Fuels

INTERNATIONAL:

International Energy Analysis; Petroleum and Contingency Analysis

International Energy Statistics; Country Production and Consumption of Major Fuels

\section{ECONOMIC:}

Corporate Finance

Energy Taxation

Foreign Investment

\section{FORECASTS:}

Annual Energy Outlook/Midterm Projections

Coal Production/Minemouth Prices/Midterm

Projections

Coal Distribution/End-Use Prices/Midterm

Projections

Coal Exports/Midterm Projections

Commercial Demand/Midterm Projections

Crude Oil Supply/Midterm Projections $\begin{array}{lr}\text { John Wood } & (214) 767-2200 / \text { jwood } \\ \text { FAX:767-2204 }\end{array}$

\begin{tabular}{lll} 
FAX Number: & $\mathbf{5 8 6 - 0 0 1 8}$ & \\
\hline Martha Johnson & $586-1135$ & mjohnson \\
Eugene Burns & $586-1125$ & eburns \\
$\begin{array}{l}\text { Samuel E. Brown } \\
\text { John Preston }\end{array}$ & $586-5103$ & $\begin{array}{l}\text { sbrown } \\
\text { jpreston }\end{array}$ \\
$\begin{array}{l}\text { John Preston } \\
\text { Wendel Thompson }\end{array}$ & $586-1128-1128$ & jpreston \\
Wendel Thompson & $586-1119$ & wthompso \\
Ron Lambrecht & $586-4962$ & rlambrec \\
Ron Lambrecht & $586-4962$ & rlambrec \\
Julia F. Hutchins & $586-5138$ & $\begin{array}{l}\text { jhutchin } \\
\text { lcarleto }\end{array}$
\end{tabular}

FAX Number:

586-9753

Derriel Cato

586-6574

dcato

Louis DeMouy

586-6557

ldemouy

FAX Number:

586-9753

Jon A. Rasmussen

586-1449

Dennis W. Sumner

586-8597

Jon A. Rasmussen

586-1449

jrasmuss

dsumner

jrasmuss

FAX Number:

586-3045

Susan H. Shaw

586-4838

586-2136

sshaw

Michael Mellish

586-2415

rnewcomb

Richard Newcombe

586-2152

Melinda Hobbs

586-5359

mhobbs

Barry N. Cohen

586-6408 bcohen wtrapman

(Continued on next page.) 
All telephone numbers are in area code 202, except where noted otherwise.

Each FAX number applies to all names that follow.

Each Internet name is followed with @eia.doe.gov

\begin{tabular}{|c|c|c|c|}
\hline 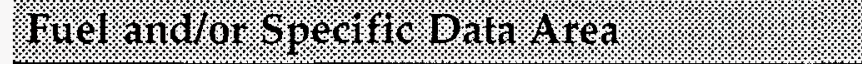 & Name & Melephore. & Internet \\
\hline FORECASTS (cont'd): & FAX Number: & $586-3045$ & \\
\hline Electricity Generation and Cost/Midterm Projections & J. Alan Beamon & $586-2025$ & abeamon \\
\hline Electricity Prices/Midterm Projections & Art Holland & $586-2026$ & aholland \\
\hline Greenhouse Gases & Arthur Rypinski & $586-8425$ & arypinsk \\
\hline Industrial Demand/Midterm Projections & T. C. Honeycutt & $586-1420$ & choneycu \\
\hline International/Midterm Projections & A. David Sandoval & $586-6581$ & -- \\
\hline \multirow[t]{2}{*}{ Macroeconomic Analysis/Midterm Projections } & Ronald F. Earley & $586-1398$ & rearley \\
\hline & Kay A. Smith & $586-1455$ & ksmith \\
\hline \multirow[t]{2}{*}{ National Energy Modeling System } & Mary J. Hutzler & $586-2222$ & mhutzler \\
\hline & Susan H. Shaw & $586-4838$ & sshaw \\
\hline Natural Gas Markets/Midterm Projections & James Diemer & $586-6126$ & jdiemer \\
\hline Natural Gas Supply/Midterm Projections & William A. Trapmann & $586-6408$ & wtrapman \\
\hline $\begin{array}{l}\text { Nuclear Energy, Domestic and International/ } \\
\text { Midterm and Long-Term Projections }\end{array}$ & Robert T. Eynon & $586-2315$ & reynon \\
\hline Petroleum Product Markets/Midterm Projections & Bruce Bawks & $586-6579$ & bbawks \\
\hline Renewable Energy/Midterm Projections & Perry Lindstrom & $586-0934$ & plindstr \\
\hline Residential Demand/Midterm Projections & Barry N. Cohen & $586-5359$ & bcohen \\
\hline $\begin{array}{l}\text { Short-Term Energy Forecasts-Supply, Demand, } \\
\text { and Prices }\end{array}$ & David W. Costello & $\begin{array}{c}586-1468 / \\
\text { FAX: } 586-9753\end{array}$ & dcostell \\
\hline Transportation Demand/Midterm Projections & David Chien & $586-3994$ & dchien \\
\hline World Oil Prices/Midterm Projections & G. Daniel Butler & $586-9503$ & gbutler \\
\hline STANDARDS AND STATISTICAL METHODS: & FAX Number: & $254-9700$ & \\
\hline Data and Modeling Quality & Doug Hale & $254-5380$ & dhale \\
\hline EIA Metric Program & Jay Casselberry & $254-5348$ & jcasselb \\
\hline EIA Standards Program & Jay Casselberry & $254-5348$ & jcasselb \\
\hline
\end{tabular}



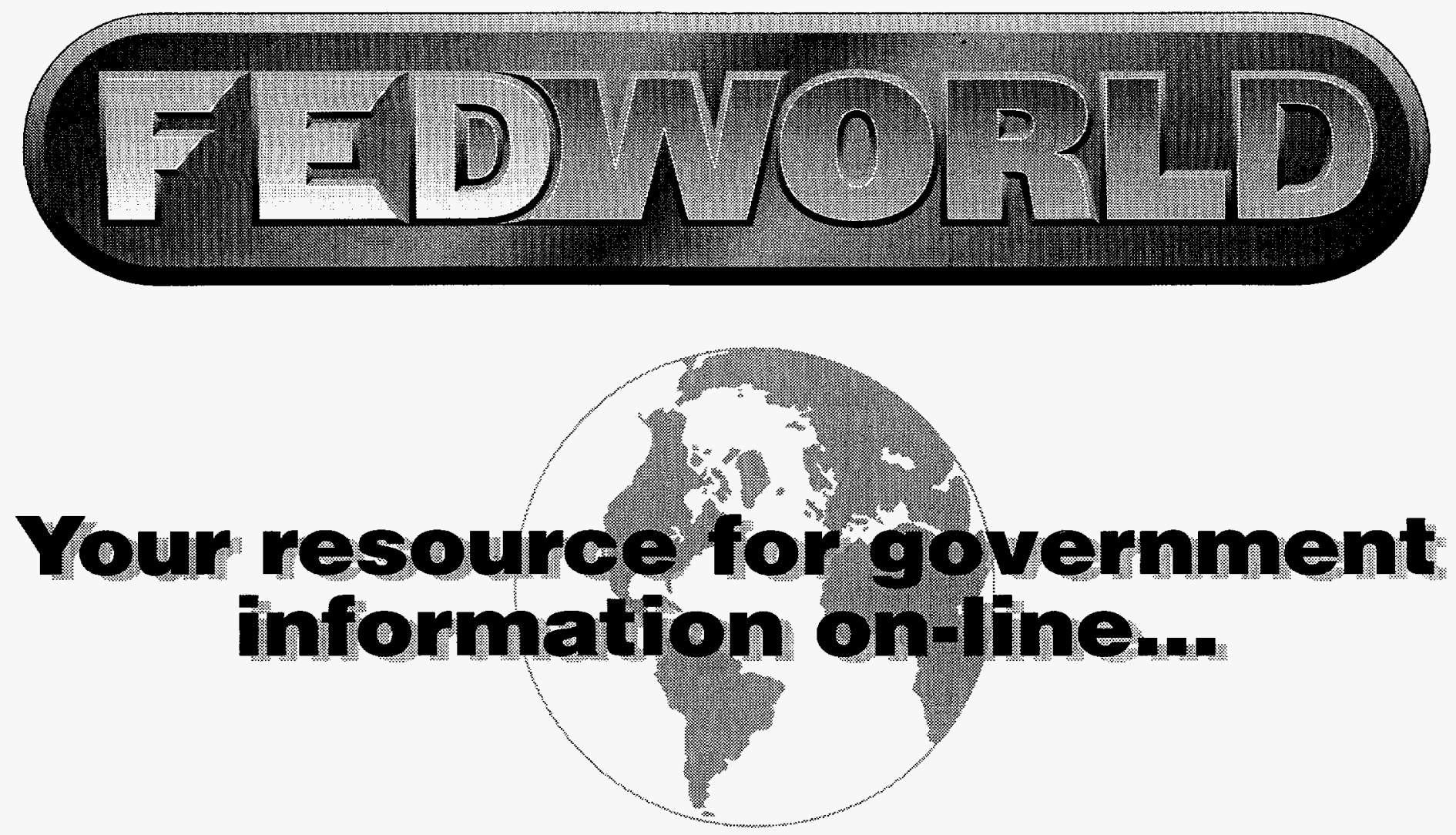

The FedWorld Information

Network is an on-line information service established by the

National Technical Information Service to provide the general public with a user-friendly, central resource for government information in electronic formats.

FedWorld provides free dial-up and Internet access to information from many different government agencies and programs.
NTIS receives thousands of

reports and documents from U.S. government agencies each week. With our new Thirty-day Preview Database, FedWorld users qan . now view abstracts of these documents as they are added to the collection.

Each abstract is accessible for 30 days, until it is replaced by newer material. FedWorld's sophisticated search software will allow you to locate and view these abstracts easily. To find out more about FedWorld, connect today.

\section{FedWorld Preview Database}

Connect to FedWorld with your modem. The modem connection number is (703) 321-FEDW (3339). If you have access to Internet, telnet to fedworld.gov.

Then, at the main menu, type /go NTISPREV. For World Wide Web Services, point your browser to http://www.fedworld.gov and click on Recent U.S. Government Reports.

For assistance, call the Help Desk at (703) 487-4608.

\section{To connect to FedWorld ${ }^{\circ}$}

\section{By Modem}

Set modem parity to none, data bits to 8 and stop bit to 1 . Set terminal emulation to ANSI. Set duplex to full. Then just dial FedWorld at (703) 321-FEDW (3339).
Telnet to fedworld.gov. For Internet File Transfer Protocol (FTP) services, connect to ftp.fedworld.gov. For World Wide Web services, point your browser to open the URL http://www. fedworld.gov. 


\section{GPO Orders}

Order Processing Code:

7759

Publications

Qty.

\begin{tabular}{|c|c|}
\hline Qty. & Stock Number \\
\hline & \\
\hline & \\
\hline & \\
\hline & \\
\hline & \\
\hline & \\
\hline
\end{tabular}

Please Type or Print (Form is aligned for typewriter use.)

\section{Superintendent of Documents Publications and Subscriptions Order Form}

Charge your order.
It's Easy!

To fax your orders (202) 512-2250

\section{Subscriptions}

\begin{tabular}{|c|c|c|c|c|}
\hline Qty. & (List ID) & Title & $\begin{array}{c}\text { Price } \\
\text { Each }\end{array}$ & $\begin{array}{c}\text { Total } \\
\text { Price }\end{array}$ \\
\hline & & & & \\
\hline & & & & \\
\hline & & & & \\
\hline & & & & \\
\hline
\end{tabular}
NoTE: Prices include regular domestic postage and handling and are subject to change. Total for Subscriptions
International customers please add 25\%.
Total Cost of Order

(Company or Personal Name)

(Please type or print)

(Additional address/attention line)

(Street address)

(City, State, ZIP Code)

(Daytime phone including area code)

(Purchase Order No.)

Mail To: Superintendent of Documents

P.O. Box 371954, Pittsburgh, PA 15250-7954
For privacy protection, check the box below:

$\square$ Do not make my name available to other mailers

Please choose method of payment:

$\square$ Check Payable to the Superintendent of Documents

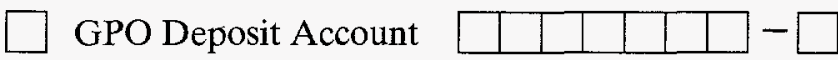

$\square$ VISA or MasterCard Account

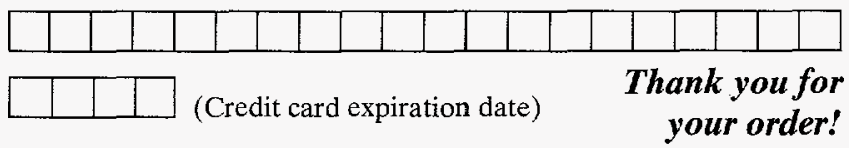

(Authorizing Signature) 


\section{NTIS Orders}

\section{U.S. DEPARTMENT OF COMMERCE TECHNOLOGY ADMINISTRATION \\ ORDER FOAM}

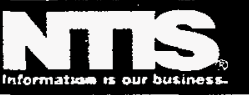

\section{SHIF TO ADORESS}

CUSTOMER MASTER NUMBER (IF KNOWN)

ATTENTIONNANE

ORGANIZATION

DNISION / ROOM MUMBER

\section{STREET ADORESS}

\begin{tabular}{ll|l}
\hline CITY STATE & ZIP COOE \\
\hline PROVINCE / TERRTORY & FOREIGN PCSTA CODE
\end{tabular}

COUNTRY

\begin{tabular}{l|l|}
\hline PHONE NUMBER & FAX MUMBER \\
\hline
\end{tabular}

\section{METHOD OF PAYMENT}

$\square$ Check / Money Order enclosed for \$

(PAYABLE IN U.S. DOLLARS)

$\square$ NTIS Deposit Account Number:

\begin{tabular}{l}
$\square$ VISA $\square$ MasterCard $\square$ American Express \\
\hline CREDIT CARO NUMBER
\end{tabular}

CARDHOLDERS NAME

SIGNATURE (REQUIRED TO VALIDATE ALL ORDERS)
DTIC USERS ONLY

COOE

CONIRACT NUMBER RAST SIX DUGTS

ORDER BY PHONE (EMNATE MAL TME)

S:30 a.m. - 5:00 0.m. Eastem Time, M - F.

Sales Desk: (703) $487-4650$

Sibscriptions: (703) $487-4630$

TD (hearing impaired only): (703) 487-4630

OADER BY FUX

24 hours $/ 7$ davs a week: (703) 321.8547

To verify receipl of fax: cail (703) 487-4679

7:00 a.m. - 5:00 p.m., Eastem Time, $M-F$.

ORDER BY MNL

National Technicai Information Service

\$285 Port Royal Road

Soringfield, VA 22161

RUSH SERVMCE (DO NOT MAL RUSH ORDESS)

:-800-553-NTIS

RUSH service avaliable for aoditional fee.

FEDworlo

Please call for connect information: (703) 487-4608.

BUL ME

U.S. Canada, and Mexico only.)

DO NOT USE THIS FORM.

NTIS will gladly bill your order, for an additional fee of

57.50. A request to be billed must be on a purchase order a company letterhead. An authorizing signature, contact rame, and telephone number should be incuded with this request. Requests may be mailed or faxed.

\begin{tabular}{|c|c|}
\hline \multicolumn{2}{|c|}{ NTIS HANDLING FEE } \\
\hline Value of Order & Hending Fee \\
\hline $\begin{array}{l}\$ 10.00 \text { or less } \ldots \\
\$ 10.01-\$ 50.00 \\
\$ 50.01-\$ 100.00 \\
\text { Over } \$ 100.00\end{array}$ & $\begin{array}{r}\$ 2.00 \\
\$ 4.00 \\
\$ 6.00 \\
\$ 8.00\end{array}$ \\
\hline
\end{tabular}

Add $\$ 2.00$ to handing fee for orders sent outside the Unted States. Canada, and Mexoco.

PRODUCT SELECTION

\begin{tabular}{|c|c|c|c|c|c|c|c|c|c|}
\hline \multirow{2}{*}{\multicolumn{2}{|c|}{$\begin{array}{l}\text { NTIS PRODUCT NUMBER } \\
\text { (ORDERING BY TIME ALIONE } \\
\text { WILL DELAY YOUR ORDER) } \\
\end{array}$}} & \multirow{2}{*}{$\begin{array}{l}\text { NTERNAL CUSTOMER } \\
\text { ROUTHG YOPTIONAL } \\
\text { IP TO \& CHARACTERS }\end{array}$} & \multirow{2}{*}{$\begin{array}{l}\text { UNRT } \\
\text { PRXCE }\end{array}$} & \multicolumn{6}{|c|}{ QUAATTIY } \\
\hline & & & & $\begin{array}{l}\text { PAPER } \\
\text { COPY }\end{array}$ & $\begin{array}{l}\text { MICRO } \\
\text { FICHE }\end{array}$ & $\begin{array}{l}\text { MAGNETKC } \\
\text { TAPE * }\end{array}$ & DSRETE & CD-ROM & OTHER \\
\hline \multicolumn{3}{|c|}{$A G X$} & $\$$ & & & & & & \\
\hline \multicolumn{3}{|c|}{ AGX } & $\$$ & & & & & & \\
\hline \multicolumn{3}{|c|}{ AGX } & $\$$ & & & & & & \\
\hline \multicolumn{3}{|c|}{ AGX } & $\$$ & & & & & & \\
\hline \multicolumn{3}{|c|}{$A G X$} & $\$$ & & & & & & \\
\hline \multirow{2}{*}{$\begin{array}{l}* \text { CRCLE } \\
\text { REOUREAENTS }\end{array}$} & \multirow{2}{*}{$\begin{array}{l}3480 \\
\text { CARTRIDGE }\end{array}$} & \multirow{2}{*}{$\begin{array}{l}1800 \\
B P 1\end{array}$} & \multicolumn{2}{|c|}{ LABELING } & \multicolumn{3}{|c|}{ FORMAT } & & \\
\hline & & & STANOARD & NONLABELED & & DIC & Asca & & \\
\hline
\end{tabular}

\section{PLEASE NOTE}

Unless microfiche or other is specified. paper copy will be sent.

Please call the Sales Desk at (703) $487-4650$ for information on multiple copy discounts available for certain documents, retum policy, and price verification.

Out-Of-Print Surcharge

Effective 4/17/95, an out-of-print surcharpe may apply to certain tites acquired by NTS more than three years prior $\mathrm{b}$ the current calendar year, please call to vertiy price.

International Aimail Fees

Canada and Mexico add $\$ 4$ per paper copy report $\$ 1$ per mic ofiche copy. Other countries add $\$ 8$ per paper cooy report $\$ 1.25$ per microfiche copy. (Paper copy reports and microfiche copies are shipped surface mail unless airmal is spectied.)

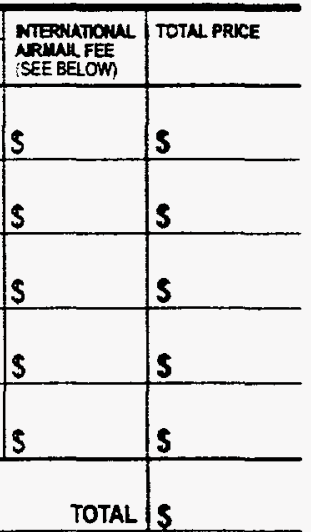

\section{HANDLING FEE}

PER ORDER ISEE CHART ABOVE

GRAND TOTAL $S$

Thande yace for wane andorl Prices are subject to change. All previous versions of this form are obsolete. 


\section{NEIC Orders}

\section{NATIONAL ENERGY INFORMATION CENTER ORDER FORM \\ TO ORDER FREE PUBLICATIONS--TO NOTIFY NEIC OF CHANGE OF ADDRESS -TO CANCEL A MAILING LIST PUBLICATION}

Mail to: National Energy Information Center, El-231

Energy Information Administration

Room 1F-048, Forrestal Building

Washington, DC 20585

Name

Business Affiliation

Mail List I.D. Number

(Found in upper left corner of your mailing label.)

\section{Address}

City and State

Zip Code

$\frac{(1)}{\text { Phone number with area code }}$

$\frac{(1)}{\text { FAX Number }}$

Change of address.

$\square$ Add name to mailing list for free publication(s) as listed below.

$\square$ Take name off mailing list for publication(s) as listed below.

$\square$ Send the free publication(s) as listed below. 